УДК 615.214.32:615.9:543.544.6.

DOI 10.11603/mcch.2410-681X.2018.v0.i4.9828

Н. В. Горлачук, Л. М. Мосула, Н. О. Зарівна

ТЕРНОПІЛЬСЬКИЙ ДЕРЖАВНИЙ МЕДИЧНИЙ УНІВЕРСИТЕТ ІМЕНІ І. Я. ГОРБАЧЕВСЬКОГО

\title{
ХРОМАТО-МАС-СПЕКТРОМЕТРИЧНИЙ АНАЛІЗ ТІАНЕПТИНУ В СЕЧІ
}

Вступ. Коаксил (тіанептин) є антидепресантом нового покоління із селективно-серотонінергічною дією. Останнім часом в Україні відмічають значне збільшення немедичного використання атипового трициклічного антидепресанту - тіанептину. За даними вітчизняних наркологів та психіатрів, ним зловживають наркомани. У літературних джерелах є відомості про те, що цей лікарський засіб поєднує в собі властивості опію, героїну та кокаїну. Приймання тіанептину у великих дозах (400-600 мг внутрішньовенно) призводить до стану ейфорії і дає наркотичний ефект у декілька разів сильніший, ніж героїн та кокаїн.

мета дослідження - вивчити і визначити метаболіти тіанептину, що утворюються в організмі людини та які виявляють у сечі в ході досліджень методом газової хроматограсрії і хромато-мас-спектромempiï.

Meтоди дослідження. Аналіз проводили на газовому хроматографрі Agilent 6890N із мас-селективним детектором Agilent 5973 і автоінжектором Agilent 7683 (США), обладнаному хроматографрічною кварцовою капілярною колонкою FactorFOUR фрірми "Varian" (США). Газ-носій - гелій.

Результати й обговорення. Результати аналізу екстрактів, отриманих як при кислих, так і при лужних значеннях $\mathrm{pH}$, показали наявність у них метаболіту тіанептину МС5. Крім основного метаболіту MC5, в екстрактах, одержаних при рН 3-4, були також присутні дезалкілдезамінотіанептин і дезалкілдезамінонортіанептин, а в екстрактах, отриманих при рH 9-10, - дезалкілтіанептин і метаболіт, структуру якого на даний момент встановити не вдалося. На основі того, що головний метаболіт тіанептину МС5 ізолюється із сечі як при кислих значеннях рH (рH 3-4), так і при лужних (рH 9-10), для хромато-мас-спектрометричного його аналізу можна використовувати і кислі, і лужні екстракти.

Висновки. Показано можливість використання методів газової хроматографрії та хромато-мас-спектрометрії для аналізу метаболітів. Основний метаболіт тіанептину може ізолюватися із сечі при кислих, а також лужних значеннях рН середовища.

КЛЮЧОВІ СЛОВА: тіанептин; метаболіти; хромато-мас-спектрометрія; екстракти; антидепресанти.

ВСТУП. Коаксил (тіанептин) є антидепресантом нового покоління із селективно-серотонінергічною дією (стимуляція зворотного захоплення серотоніну), який з часу впровадження (1988 р.) широко застосовують у терапії депресивних розладів [1, 2]. На сьогодні коаксил - другий за частотою використання антидепресант (після амітриптиліну), який призначають більш ніж 20 \% пацієнтів з депресією в психіатричних клініках. Однак дані щодо застосування коаксилу, як і практично всіх антидепресантів нового покоління, в умовах стаціонару вкрай обмежені [3, 4].

Останнім часом в Україні відмічають значне збільшення немедичного використання атипового трициклічного антидепресанту - тіанептину (Tianeptine, коаксил) [5]. У медичній практиці препарати, в яких міститься даний активний фармацевтичний інгредієнт, застосовують при лікуванні депресивних станів різного ступеня (c) Н. В. Горлачук, Л. М. Мосула, Н. О. Зарівна, 2018. тяжкості, в тому числі у хворих на хронічний алкоголізм в абстинентний період; тривожнодепресивного стану, обтяженого соматичними скаргами; органічних депресивних і тривожних розладів; неврастенії, а також гострої реакції на стрес і посттравматичний стресовий розлад [6].

При регулярному використанні доз, які в десятки разів перевищують медичні, й виключно при внутрішньовенному шляху введення тіанептин викликає тяжку лікарську залежність [7]. Як правило, з метою наркотичного вживання кустарно виготовляють ін'єкційні варіанти таблеткових препаратів даної речовини. При цьому клінічна картина інтоксикації подібна до героїнової залежності, через що багато наркоманів замінює тіанептином героїн. Однак така схожість поширюється і на синдром відміни. Часте зловживання кустарними препаратами тіанептину призводить до тяжких наслідків: сліпоти, ампутації кінцівок, швидкого летального кінця [8]. 
Тіанептин (коаксил) - оригінальний трициклічний антидепресант дибензотіазепінового ряду. Згідно з літературними даними, в організмі людини основним шляхом його метаболізму $€ \beta$-окиснення алісратичного замісника при атомі азоту, в результаті якого утворюються два активних метаболіти: з бічними ланцюгами пропіонової (метаболіт МС5) і валеріанової кислот (метаболіт МС3). Крім цього, в сечі можуть бути присутні продукти N-дезалкілювання даної речовини. 3224 год у незміненому вигляді з організму виводиться менше ніж 3 \% дози, яка надійшла [9].

Молекула тіанептину містить хімічні угруповання кислого і лужного характеру, а також довгий ліпофільний аліфатичний "хвіст". Він має досить велику молекулярну масу. Всі ці фрактори створюють труднощі при аналізі біорідин на фракт присутності тіанептину методами газової хроматограсрії і хромато-мас-спектрометрії. Для успішного дослідження даними методами цієї речовини зазвичай здійснюють дериватизацію активних угруповань одним або декількома реактивами. Однак, як показує практика, в разі вживання тіанептину з метою одержання наркотичного ефекту в сечі містяться продукти його метаболізму або розпаду.

Мета дослідження - вивчити і визначити метаболіти тіанептину, що утворюються в організмі людини та які виявляють у сечі в ході досліджень методом газової хроматограсрії і хромато-мас-спектрометрії.

МЕТОДИ ДОСЛІДЖЕННЯ. Аналіз проводили на газовому хроматографрі Agilent $6890 \mathrm{~N}$ із мас-селективним детектором Agilent 5973 і автоінжектором Agilent 7683 (США), обладнаному хроматографрічною кварцовою капілярною колонкою FactorFOUR фрірми "Varian" (США) довжиною 30 м, внутрішнім діаметром 0,25 мм, товщиною фрази 0,25 мкм. Газ-носій - гелій, швидкість його потоку через колонку - 1,2 мл/Хв, лінійна швидкість - 41 см/с. Температура випаровувача підтримувалася в межах $250^{\circ} \mathrm{C}$. Режим програмування температури термостата колонки: від 110 до $290{ }^{\circ} \mathrm{C}$ нагрівали зі швидкістю $25^{\circ} \mathrm{C} /$ хв і витримували 7,8 хв при кінцевій температурі. Загальний час аналізу - 16 хв. Пробу вводили в режимі з діленням потоку (split) 1:20. Об'єм внутрішньої проби становив 1 мкл. Температура квадрополя $-150{ }^{\circ} \mathrm{C}$, температура джерела іонів $-230^{\circ} \mathrm{C}$. Використовували іонізацію електронним ударом при 70 еВ у режимі сканування повного іонного потоку (SCAN) в діапазоні від 50 до 550 m/z.

Проби сечі по 2 мл доводили до значень $\mathrm{pH}$, що перебували в інтервалі 1-2; 3-4; 7; 9-10, і додавали по 3 мл діетилового ефіру. Для створення рН в інтервалі від 1 до 4 використовували 2 г/л кислоти хлористоводневої $P$, а для $\mathrm{pH}$ 9-10 - 5 г/л гідроксиду калію. Після струшування (10 хв при 120 об./Хв) і центрифругування (10 хв при 3000 об./хв) верхній органічний шар обережно відбирали одноразовою пластиковою піпеткою і переносили для випарювання в скляну конічну пробірку об'ємом 10 мл. Випарювання здійснювали при кімнатній температурі в струмі холодного повітря до сухого залишку. Сухий залишок 200 мкл розчиняли в 10 мл 96 \% спирту етилового і переносили у скляні вставки. Як внутрішній стандарт у кінцевий екстракт додавали 20 мкл 0,05 \% метанольного розчину дифреніламіну фрірми "Sigma" (США).

РЕЗУЛЬТАТИЙ ОБГОВОРЕННЯ. РеЗУЛЬТаТИ аналізу екстрактів, отриманих як при кислих, так і при лужних значеннях $\mathrm{pH}$, показали наявність у них метаболіту тіанептину МС5. Цікавий той фракт, що в процесі аналізу детектується метаболіт MC5 (а саме його лактонне похідне), а сам тіанептин і його метаболіт МСЗ не детектуються.

Ми зробили припущення про те, що процес введення проби в інжектор хроматограсра, а також процес хроматограсрічного розділення компонентів відбуваються при відносно високій температурі, метаболіт МС5 за цих умов втрачає воду з утворенням лактонного похідного МС5$\mathrm{H}_{2} \mathrm{O}$. Запропоновану схему процесу утворення лактону наведено на рисунку 1.

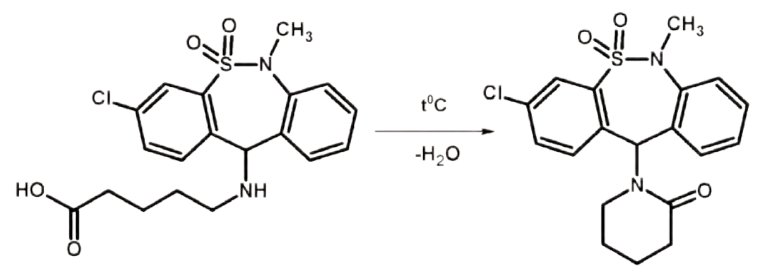

Рис. 1. Процес утворення лактону метаболіту MC5.

Дана фрормула підтверджується тим фрактом, що обробка екстрактів сечі, як кислих, так і лужних, оцтовим або трисртороцтовим ангідридом у лужному середовищі не призводить до зменшення чи повного зникнення метаболіту.

Крім основного метаболіту МС5, в екстрактах, одержаних при pH 3-4, були також присутні побічні метаболіти MC1 і МС3 - дезалкілдезамінотіанептин та дезалкілдезамінонортіанептин, а в екстрактах, отриманих при рH 9-10, - дезалкілтіанептин і метаболіт, структуру якого на даний момент встановити не вдалося. У цілому вихід метаболіту МС5 при використанні пробопідготовки зі створенням лужних значень $\mathrm{pH}$ сечі зазвичай більший, ніж при кислих значеннях. Результати наведено в таблиці. 
Таблиця - Площа піків метаболітів тіанептину при використанні різних способів пробопідготовки (аналіз методом хромато-мас-спектрометрії)

\begin{tabular}{|c|c|c|c|}
\hline \multirow{2}{*}{ Метаболіт } & \multicolumn{3}{|c|}{$\mathrm{pH}$} \\
\hline & $1-2(n=10)$ & & $9-10(n=10)$ \\
\hline MC5 & $52,75 \pm 1,79$ & & $98,73 \pm 1,41$ \\
\hline MC1 i MC3 & 0 & 0 & $11,61 \pm 2,63$ \\
\hline$t(P=0,95)$ & \multicolumn{3}{|c|}{$\begin{array}{c}\text { t2 i } 3-9,81 \\
\text { t2 i } 4-21,85 \\
\text { t2 i } 5-18,77 \\
\text { t3 i } 4-9,29 \\
\text { t3 i } 5-5,03 \\
\text { t4 i } 5-6,25\end{array}$} \\
\hline
\end{tabular}

У деяких зразках сечі, після пробопідготовки при лужних значеннях рН, детектується ще ряд метаболітів, структурну формулу яких на сьогодні поки що не встановлено. Хроматограми кислого і лужного екстрактів сечі людини, яка приймала коаксил, і мас-спектри метаболітів наведено на рисунках 2, 3.

На основі одержаних даних ми представили можливу схему метаболізму тіанептину, яку наведено на рисунку 4.

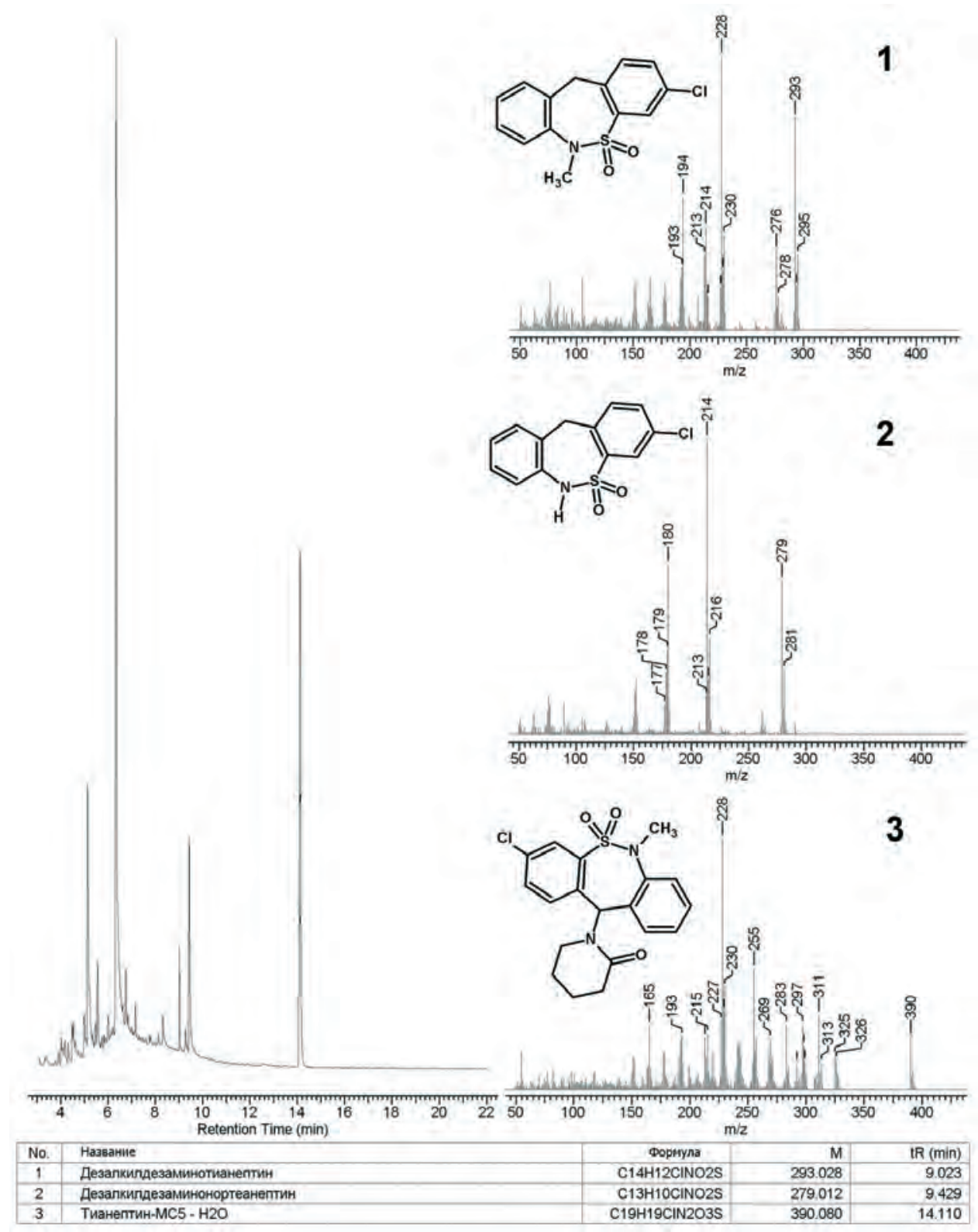

Рис. 2. Хроматограма кислого екстракту сечі й мас-спектри метаболітів. 


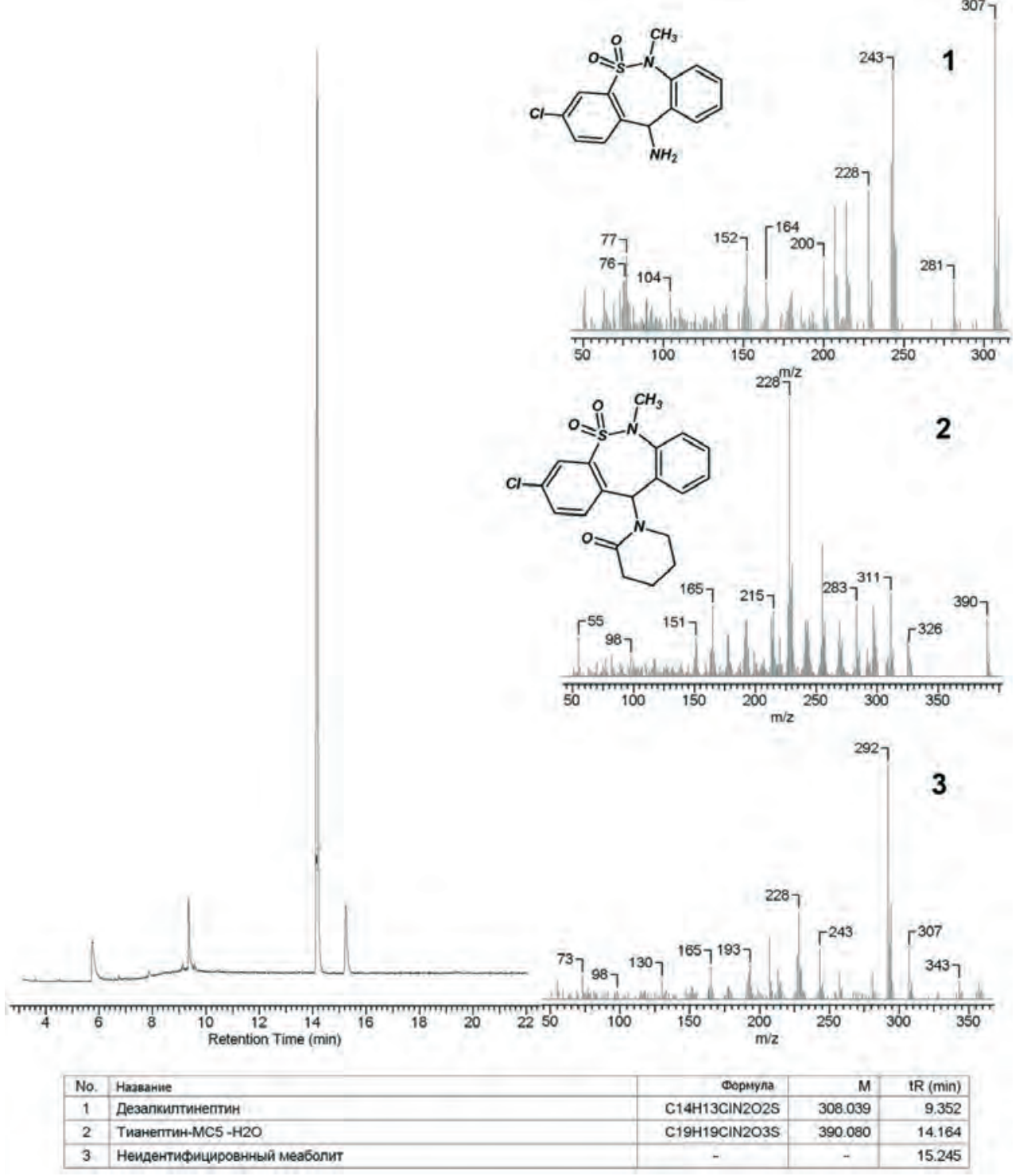

Рис. 3. Хроматограма лужного екстракту сечі й мас-спектри метаболітів.

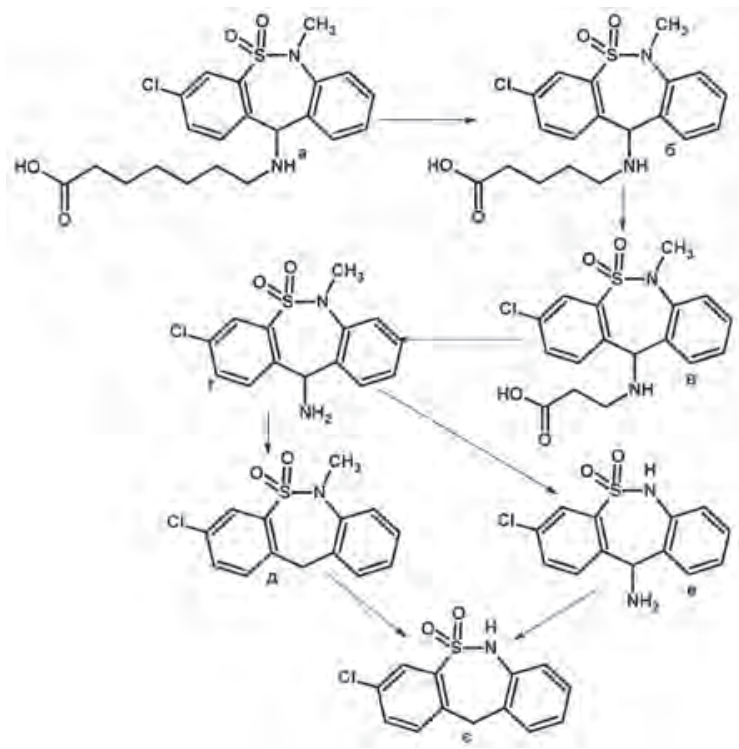

Рис. 4. Схема метаболізму тіанептину: а - тіанептин; б - метаболіт МС5; в - метаболіт МСз; г - дезалкілтіанептин; д - дезалкілдезамінотіанептин; е - дезалкілнортіанептин; $€$ - дезалкілдезамінонортіанептин. 
На основі того, що головний метаболіт тіанептину МС5 ізолюється із сечі як при кислих значеннях $\mathrm{pH}(\mathrm{pH} 3-4)$, так і при лужних (pH 9-10), для хромато-мас-спектрометричного його аналізу можна використовувати і кислі, і лужні екстракти. При цьому на практиці останні екстракти застосовують для виявлення продуктів розпаду тіанептину методами тонкошарової

\section{СПИСОК ЛІТЕРАТУРИ}

1. Раневский К. С. Антидепрессанты: нейрохимические аспекты механизма действия / К. С. Раневский // Психиатрия и психофрармакотерапия. - 2010. 1, № 3. - С. 35-38.

2. Caccia S. Metabolism of the newer antidepressants / S. Caccia // Clin. Pharmacokinet. - 2009. No. 34 (4). - P. 292-294.

3. Labrid C. Neurochemical and pharmacological properties of tianeptine, a novel anti-depressant / C. Labrid, E. Mocaer, A. Kamoun // Br. J. Psychiatry. 2009. - No. 160. - P. 56-60.

4. Fromenty B. Tianeptine, a new tricyclie antidepressant metabolized by beta - oxidation of its heptanoic side chain, inhibits the mitochondrial oxidation of medium and short chain fatty acids in mice / B. Fromenty, E. Freneaux, Q. Lable // Biochem. Pharmacol. - 2009. - 1, No. 21. P. 43-51.

5. Leterme L. Misuse of tianeptine: five cases of abuse / L. Leterme, Y. S. Singlan, V. Auclair // Ann. Med. In. - 2008. - No. 2. - P. 58-63.

\section{REFERENCES}

1. Ranevskiy, K.S. (2010). Antidepressanty: neyrokhimicheskiye aspekty mekhanizma deystviya [Antidepressants: neurochemical aspects of mechanism]. Psykhiatriya i psikhofarmakoterapiya - Psychiatry and Psychopharmacotherapy, 1, (3), 35-38 [in Russian].

2. Caccia, S. (2009). Metabolism of the newer antidepressants. Clin. Pharmacokinet., 34, (4), 292-294.

3. Labrid, C., Labrid, C., Mocaer, E., \& Kamoun, A. (2009). Neurochemical and pharmacological properties of tianeptine, a novel anti-depressant. Br. J. Psychiatry, 160, 56-60.

4. Fromenty, B., Fromenty,B., Freneaux, E., \& Lable, Q. (2009). Tianeptine, a new tricyclie antidepressant metabolized by beta - oxidation of its heptanoic side chain, inhibits the mitochondrial oxidation of medium and short і газової хроматограсрії чи хромато-мас-спектрометрії.

ВИСНОВКИ. 1. Показано можливість використання методів газової та хромато-мас-спектрометрії для аналізу метаболітів.

2. Основний метаболіт тіанептину може ізолюватися із сечі при кислих, а також лужних значеннях $\mathrm{pH}$ середовища.

6. Рябцева А. Токсическое поражение органа зрения у иньекционных потребителей тианептина / А. Рябцева, Ю. Бардеева // Наркология. - 2013. № 1. - C. 25-28.

7. Gaulier J.-M. High-performance liquid chromatographic determination of tianeptine in plasma applied to pharmacokinetic studies / J.-M. Gaulier, P. Marquet, E. Lacassie // J. Chromatogr. B. - 2012. - No. 748. P. 407-414.

8. Caccia S. Metabolism of the newer antidepressants. An overview of the pharmacological and pharmacokinetic implications / S. Caccia // Clin. Pharmacokinet. 2008. - 34, No. 4. - P. 281-302.

9. Santana F. Enantioselective analysis of mianserin and its two major metabolites in human plasma by liquid chromatography-mass spectrometry after three phase liquid phase microextraction / F. Santana, P. Bonato // Anal. Chim. - 2008. - 606, No. 1. - P. 80-91. chain fatty acids in mice. Biochem. Pharmacol., 1, (21), 43-51.

5. Leterme, L., Singlan, Y., \&Auclair, V.(2008). Misuse of tianeptine: five cases of abuse. Ann. Med. In., 2, 58-63.

6. Ryabtseva, A., \& Bardeeva, Yu. (2013). Toksicheskoye porazheniya organa zreniya $u$ inyektsionykh potrebiteley tianeptina [Toxic damage to the visual organ in injecting tinaptine users]. Narkologiya - Narcology, 1, 25-28 [in Russian].

7. Gaulier, J.M., Marquet, P., Lacassie, E. (2012). High-performance liquid chromatographic determination of tianeptine in plasma applied to pharmacokinetic studies. J. Chromatogr. B., 748, 407-414.

8. Caccia, S. (2008). Metabolism of the newer antidepressants. An overview of the pharmacological and 
pharmacokinetic implications. Clin. Pharmacokinet., 34, (4), 281-302.

9. Santana, F., Bonato, P. (2008). Enantioselective analysis of mianserin and its two major metabolites in human plasma by liquid chromatography - mass spectrometry after three phase liquid phase microextraction. Anal. Chim. 606, (1), 80-91.

Н. В. Горлачук, Л. М. Мосула, Н. А. Заривна ТЕРНОПОЛЬСКИЙ ГОСУДАРСТВЕННЫЙ МЕДИЦИНСКИЙ УНИВЕРСИТЕТ ИМЕНИ И. Я. ГОРБАЧЕВСКОГО

\section{ХРОМАТО-МАСС-СПЕКТРОМЕТРИЧЕСКИЙ АНАЛИЗ ТИАНЕПТИНА В МОЧИ}

\section{Резюме}

Вступление. Коаксил (тианептин) является антидепрессантом нового поколения с селективно-серотонинергическим действием. В последнее время в Украине отмечают значительное увеличение немедицинского использования атипического трициклического антидепрессанта - тианептина. По данным отечественных наркологов и психиатров, им злоупотребляют наркоманы. В литературных источниках есть сведения о том, что это лекарственное средство сочетает в себе свойства опия, героина и кокаина. Прием тианептина в больших дозах (400-600 мг внутривенно) приводит к состоянию эйорории и дает наркотический эффрект в несколько раз сильнее, чем героин и кокаин.

Цель исследования - изучить и определить метаболиты тианептина, которые образуются в организме человека и которые обнаруживают в моче в ходе исследований методом газовой хроматографии и хромато-масс-спектрометрии.

Методы исследования. Анализ проводили на газовом хроматограqре Agilent 6890N с масс-селективным детектором Agilent 5973 и автоинжектором Agilent 7683 (США), оборудованном хроматографической кварцевой капиллярной колонкой FactorFOUR фрuрмы "Varian" (США). Газ-носитель - гелий.

Результаты и обсуждение. Результаты анализа экстрактов, полученных как при кислых, так и при щелочных значениях $\mathrm{pH}$, показали наличие у них метаболита тианептина МС5. Кроме основного метаболита MC5, в экстрактах, полученных при рН 3-4, также присутствовали дезалкилдезаминотианептин и дезалкилдезаминонортианептин, а в экстрактах, полученных при рH 9-10, - дезалкилтианептин и метаболит, структуру которого на данный момент установить не удалось. На основе того, что главный метаболит тианептина МС5 изолируется из мочи как при кислых значениях рН (рH 3-4), так и при щелочных (рН 9-10), для хромато-масс-спектрометрического его анализа можно использовать и кислые, и щелочные экстракты.

Выводы. Показана возможность использования методов газовой хроматографии и хромато-масс-спектрометрии для анализа метаболитов. Основной метаболит тианептина может изолироваться из мочи при кислых, а также щелочных значениях рН среды.

КЛЮЧЕВЫЕ СЛОВА: тианептин; метаболиты; хромато-масс-спектрометрия; экстракты; антидепрессанты.

N. V. Horlachuk, L. M. Mosula, N. O. Zarivna I. HORBACHEVSKY TERNOPIL STATE MEDICAL UNIVERSITY

\section{CHROMATOGRAPHY-MASS-SPECTROMETRY ANALYSIS OF TIANEPTINE IN URINE}

\section{Summary}

Introduction. Coaxil (tianeptine) is a new generation antidepressant with selective serotoninergic action. Recently, a significant increase in non-medical use of the atypical tricyclic antidepressant drug, tianeptine, has been observed in Ukraine. According to domestic narcologists and psychiatrists there is information on tianeptine abuse 
by drug addicts. In the literature there is information that this medicine combines characteristics of opium, heroin and cocaine in it. Receiving of tianeptine in high dosages (400-600 mg intravenously) leads to a state of euphoria and gives a narcotic effect that is several times stronger than heroin and cocaine.

The aim of the study - to learn and define tianeptine metabolites in the human body, which are detected in urine, in the course of research by gas chromatography and gas chromatography-mass spectrometry.

Research Methods. The analysis has been carried out on a gas chromatograph Agilent 6890N with a massselective detector Agilent 5973 and an injector Agilent 7683 (USA) equipped with a chromatographic quartz capillary geyser of FactorFOUR Varian (USA). Gas carrier - helium.

Results and Discussion. The analysis of extracts received as with acidic and with alkaline pH values, has shown metabolites of tianeptine MC5 in them. Besides the main metabolite (MC5), there have also been dezalkyldezaminotianeptine and dezalkyldezaminonortianeptine in the extracts obtained at $\mathrm{pH} 3-4$, and in the extracts obtained at pH 9-10 - dezalkyltianeptine and a metabolite, the structure of which has not been established at the moment. Based on the fact that the main metabolite of tianeptine MC5 is isolated from the urine both at acidic $\mathrm{pH}$ values $(\mathrm{pH}=3-4)$ and at alkaline $(\mathrm{pH}=9-10)$, it is possible to use as acidic as alkaline extracts for the chromatographymass spectrometry analysis.

Conclusions. The possibility of using gas chromatography and mass spectrometry methods for metabolites has been shown. The main metabolite of tianeptine can be isolated from the urine at acidic, and also at alkaline $\mathrm{pH}$ values of the medium.

KEY WORDS: tianeptine; metabolites; chromatography-mass spectrometry; extracts; antidepressants.

Отримано 25.10 .18

Адреса для листування: Л. М. Мосула, Тернопільський державний медичний університет імені І. Я. Горбачевського, майдан Волі, 1 , Тернопіль, 46001, Україна, e-mail: mosula@tdmu.edu.ua. 